
\title{
25 Research Soure \\ Scientometric analysis of seed improvement in underutilized crops: prospects for enhancing food security
}

Dolapo Bola Adelabu ( $\sim$ solakinns@yahoo.com )

University of the Free State - Bloemfontein Campus: University of the Free State https://orcid.org/00000001-8653-9442

Angelinus C Franke

University of the Free State - Bloemfontein Campus: University of the Free State

\section{Research Article}

Keywords: Bibliometrics, funding, genetic resources; researcher, seed

Posted Date: February 7th, 2022

DOI: https://doi.org/10.21203/rs.3.rs-1313735/v1

License: (c) (i) This work is licensed under a Creative Commons Attribution 4.0 International License.

Read Full License 


\section{Abstract}

Assessing research activity is important for planning future direction and adaptive approaches. We studied the trends and research activity conducted on seed improvement of underutilized crops, where research hotspots were determined based on keywords, productive research titles, and journal sources mapped from five decades (1971 to 2021). This was done using the combined data retrieved from Web of Science and Scopus databases, loaded in bibliometric R-package and VOSviewers software tools. Our results show the annual publication growth rate in the studies was $13.7 \%$, with the increased number of studies and citations on seed improvement of underutilized crops (SUC) relating to seed genetic diversity, seed conservation, food security. Among the most cited studies or relevant researches were research findings carried out in the United Kingdom, India, USA and China. The strongest co-authorship linkages were found among researchers from India, the United Kingdom, Italy, Malaysia and the United States while Benin, Ghana and South Africa were among the most cited countries in Africa. The most cited journal source in the field was Genetic Resources and Crop Evolution which had a g-index of 14. Among the trending research focuses are; diverse genetic resources, nutritional values, seed enhancement, genetic analysis tools and farming system of the SUC. Research on SUC is rising with main themes on genetic resources, diversity, conservation and genetic tools-related studies. The SUC field still needs more international research collaboration and funding, with a focus on qualitative studies, adequate methodological procedures and advanced breeding resources that could help understand and promote seed improvement of underutilized crops.

\section{Introduction}

The underutilized crops are useful plant species that are either marginalized or ignored completely by researchers, breeders and policymakers. They are non-commodity crops and belong to a large, biodiverse group of thousands of domesticated, semi-domesticated, or wild species (Padulosi et al., 2013). Approximately $70 \%$ of the world's calories are produced from four staple crops (maize, wheat, rice, and soybean), the increase in staple crop yield from the last century can be attributed to adequate knowledge in the use of advanced tools and management techniques in genetic control of agronomic traits of the crops (Bailey-Serres et al., 2019). A similar effort can reproduce outstanding yield with underutilized crops (> 6000 species) which have greater potential to dramatically improve food production, resilient to climate change, rich in nutritional composition, high capacity to reduce pests and disease infestation and improve agricultural sustainability(Mabhaudhi et al., 2019). These potentials could be achieved with knowledge-based improvement management strategies that improve its seed improvement. However, these crops have witnessed minimal seed improvement in research while their valuable genetic resources are disappearing rapidly (Mustafa et al., 2019). Information on seed genetic analysis of underutilized crops is not readily available compared to staple crops. Few studies reported the ongoing significant efforts to increase the crop genomic resources through innovative breeding techniques for nutritional quality and yield of leguminous underutilized crops while limited studies occur on neglected vegetables, cereals, and oil crops (Ebert, 2014; Feldman et al., 2019; Popoola et al., 2019). The little documentation of 
indigenous knowledge concerning seed enhancement and genetic diversity, seed characterization using microsatellite markers, seeds quality and conservation revealed that seed quality is one of the major factors limiting underutilized crop production (Aliyu et al., 2016; Mayes et al., 2012).

To prevent total genetic loss among underutilized crop genetic resources for future sustainable utilization and food security a holistic approach needs to be adopted to improve the seed by addressing the seed system. Thus, distribute high-quality seed to the local and smallholder farmers. Seed improvement towards genetic, physiological, enhancement and physical quality is an important requirement for underutilized crops to reach these potentials (Anumalla et al., 2015; Muthamilarasan et al., 2019). All the different sectors in seed improvement of underutilized crops require extensive studies from the genetic diversity, breeding, seed production, quality control, marketing, and delivery to farmers which requires the application of sound approaches. The preservation of underutilized crop germplasm could only be guaranteed with the availability of quality seed for cropping which is vital to sustainable food security.

Poor seed quality reduces emergence time and early metabolic activities of hydrolytic enzymes and resource mobilization in seed (Afzal et al., 2016). While, nutrient homeostasis, hormonal regulation, and accumulation of compatible solutes are some mechanisms conferring biotic and abiotic stress tolerance on the underutilized crop (Mitra et al., 2021). However, limited knowledge on the molecular pathways in the seed was reported to influence the seed quality (Afzal et al., 2016). Seed improvement encompasses seed vigor, germination, breeding, and seed enhancement. Seed vigor is a complex physiological trait involving regulatory networks, integrated genetic programs, metabolic signals, and hormonal signaling pathways (Wu et al., 2017). Seed vigor ensures rapid and uniform emergence of plants, tolerance to environmental stresses, and the ability to withstand prolonged storage. To increase the vigor of seed lots, practices such as seed invigoration through priming methods are devised (Mukherjee, 2019). Several studies on breeding approaches for crops, through genomics, transcriptomics and proteomics, towards seed vigor have been identified with high efficiency in the last two decades (Kumar et al., 2020; Rajjou et al., 2012). However, those related to seed improvement of the underutilized crops are still scanty. Compilation and assessment of information and research activities on the trajectory of seed improvement of the crops will be useful for breeders, farmers, and the seeds industry to get a detailed understanding of gene action in the seed systems, and important for planning future protective and adaptive policies. Since the crops are mostly locally adapted, re-strategizing crop improvement and agronomic practices of the underutilized crop would help to identify climate-resilient varieties with enhanced grain features (Popoola et al., 2019). Therefore, the research activity on underutilized seed crops with emphasis on seed priming methods, breeding, ecophysiology, quality, nutrition, food security, biotechnology, perceptions, climate change, postharvest, genetic resources, medicinal properties, and seed commercialization studies was investigated. This investigative research on underutilized seed improvement will aid a clearer understanding of the crop agronomic traits, and management practices. Research on seed improvement of underutilized crops is a response that has a strong connection with Sustainable Development Goals (SDGs) 1, 2, 3, 8, and 15 and is based on calls for papers made by specialized and prestigious journals in the field of crop improvement, the current study was undertaken to analyze the research activity of underutilized seed improvement. 
To spot important research themes, patterns, activities, active researchers, and research institutions for future funding and planning bibliometric analysis was used. The use of a bibliometric analysis is a suitable methodology to identify the volume and growth pattern of literature focusing on seed improvement on underutilized crops. A literature search using well-known databases and search engines such as Scopus, Web of Science, and Google Scholar revealed very limited trajectory details of seed improvement of underutilized crops. Therefore, the current study will establish the first baseline data on this topic for future comparisons and for policymakers to draw plans on ways to improve underutilized crop production.

\section{Methodology}

\section{Databases}

Literature database-based descriptive bibliometric analysis was used, where peer-reviewed articles were collected from well recognized international peer-reviewed journals retrieved from Scopus and Web of Science databases. These databases were used because they are equipped with efficient search, filtering tools and have high validity. Also, they are widely known for their comprehensiveness, reliability in having high-impact scientific researches (Orimoloye et al., 2021). Data were retrieved from peer-reviewed articles that were published during the last five decades (1971 - 2021).

\section{Data search strategies}

We used keywords to build a valid search query that will retrieve as many documents as possible with minimal irrelevant results. In the field of seed improvement, many keywords could be used. However, we reviewed many articles published as "systematic reviews" or "bibliometric analyses" to build a search query for seed improvement of underutilized crops. The keywords used are "seed priming in underutilized crop" or "underutilized seed breeding" or "neglected seed quality" landraces seed" or "mutation breeding" or "seed genetic diversity" or "underutilized seed molecular characterization" or "indigenous seed priming" or "seed enhancement in underutilized crop". Other non-specific keywords used are; "tissue culture in landraces", "genome sequence of the wild cultivar" and "seed physiology", under the condition that a phrase related to "seed improvement" and "underutilized crop" were present in the title/abstract of the document. In the current study, the authors developed an extensive search query to retrieve all potential documents focusing on seed improvement of underutilized crops. The search query was built mainly on title search to make sure that the retrieved documents are obviously and directly related to seed enhancement in the underutilized crop. Documents retrieved from the search query on seed improvement of underutilized crops were called "SUC studies". The topic-specific search was used to make it easy for retrieval. To avoid non-traceable papers, the results of the search were limited to original articles and reviews excluding all other categories of documents such as abstracts, letters, and conference proceedings.

\section{Validation and duplication}


Validation of the search queries was based on two approaches. In the first approach, the top 50 cited documents in the SUC-related field were reviewed to make sure it fits within the scope of seed improvement in underutilized crops. This approach was adopted to eliminate irrelevant results by excluding documents that focused on seed improvement in staple, forage, or horticultural crops and others. The retrieved data from the two databases were imported into RStudio for removal of article duplication and conversion to a bibliographic data frame.

\section{Data processing and analysis}

The data analysis process was conducted using the Biblioshiny in R software to analyze and visualize co-authorship, citation analysis, co-occurrence, co-citation, and bibliographic coupling. Author names and author keywords were extracted for visualization. This identification yielded 24,561 and 582 publications in Scopus and Web of Science (WOS) databases respectively. The publications from each database were screened using document type, keyword-plus, English-language publications YEAR (1971-2021), discipline (agricultural and biological sciences) and excluded document types OR "undefined". Thus, we retained 164 in Scopus and 112 article publications in WOS. In addition, we excluded publications unrelated to underutilized, neglected, smart crop, indigenous crop production and crop diversification in the literature. The data from the two datasets were merged using R software then imported into Biblioshiny for analysis with a bibliometrix package in RStudio v.3.4.1. Retrieved data for bibliometric factors were further analyzed to create network visualization maps using VOSviewers software.

\section{Results}

\section{Description of the publications}

A total number of 276 publications were retrieved from the Web of Science (112 articles) and Scopus (164 articles) databases related to seed improvement in underutilized crops (SUC) from the year 1971 to 2021 (Table 1). However, the articles contain duplications which were removed using $\mathrm{R}$ program code in $\mathrm{R}$ software, resulting in 198 research documents, where $74 \%$ constituent research articles $(n=147)$, book and book chapter $(n=11)$ accounted for $0.06 \%$, conference proceedings $(n=11)$ were $0.06 \%$, while literature review publications $(n=27)$ had $0.14 \%$ of the total publications on SUC related studies within the periods. The annual publication growth rate on research relating to SUC was $13.7 \%$. This indicates a progressive growth in the field (Table 1). Although, there are very limited studies towards seed improvement in the underutilized crop from 1971 until 1990, from 1991 studies in the field (Figure 1). Research interest in SUC-related studies reached its climax in 2019 having the highest publication (64 articles). The average of the total citations on SUC-related fields showed an increasing trend from 1991 with the highest in 2005 but declined in 2007 and later pick up in the years 2008, 2013, and 2019. A reduction in the average of the total citation occurred in the year 2012 and 2017, which might be that these articles were recently published in those years and have not yet had enough time to be cited by other publications. 
Table 1

Main information of the dataset on SUC related studies

\begin{tabular}{|ll|}
\hline Timespan & $1971-2021$ \\
\hline Sources (Journals, Books, etc) & 123 \\
\hline Documents & 198 \\
\hline Average years from publication & 5.38 \\
\hline Average citations per documents & 12.09 \\
\hline Average citations per year per doc & 1.946 \\
\hline References & 11765 \\
\hline article & 147 \\
\hline article; proceedings paper & 1 \\
\hline book & 2 \\
\hline book chapter & 8 \\
\hline conference paper & 11 \\
\hline review & 27 \\
\hline Keywords Plus (ID) & 1259 \\
\hline Author's Keywords (DE) & 727 \\
\hline Authors & 879 \\
\hline Author Appearances & 1010 \\
\hline Authors of single-authored documents & 13 \\
\hline Authors of multi-authored documents & 866 \\
\hline Authors & 879 \\
\hline Author Appearances & 1010 \\
\hline Authors of single-authored documents & 13 \\
\hline Authors of multi-authored documents & 866 \\
\hline
\end{tabular}

\section{Author analysis}

One thousand and ten authors have directly or indirectly been involved in research studies and publications related to SUC. More than $99 \%$ of the publications were multiauthor, while only $0.9 \%$ of the publications were single-authored. This indicates that most publications were done in collaboration with more than one author. The highest collaboration index of 4.73 was observed during the year 1971-2021, 
among the most globally-cited author, are Ruiz et al. (2014) with the research publication titled "Quinoa biodiversity and sustainability for food security under climate change. A review", which has a total citation of 149 (Table 2). Their study expressed the importance of new stress-tolerant species that are mostly underutilized crops to have high genetic biodiversity values. Also, the beneficial traits of quinoa, Chenopodium quinoa Wild, (underutilized crop) was reviewed and reported that quinoa seed was a nutritious food source, the crop could thrive on marginalized soil and extreme weather conditions. Their study characterized quinoa seed, showed its evolution trends and its rich genetic diversity, stress tolerance traits, and the role of farmers in its preservation. 
Table 2

The topmost cited authors, articles and journal sources on SUC related fields

\begin{tabular}{|c|c|c|c|c|c|}
\hline No & Authors & Title & Year & Journal source & Citations \\
\hline 1 & Ruiz et al. & $\begin{array}{l}\text { Quinoa biodiversity and sustainability } \\
\text { for food security under climate change. } \\
\text { A review }\end{array}$ & 2014 & $\begin{array}{l}\text { Agron } \\
\text { Sustainable Dev }\end{array}$ & 149 \\
\hline 2 & $\begin{array}{l}\text { Rastogi } \\
\text { and } \\
\text { Shukla }\end{array}$ & $\begin{array}{l}\text { Amaranth: a new millennium crop of } \\
\text { nutraceutical values }\end{array}$ & 2013 & $\begin{array}{l}\text { CRIT REV FOOD } \\
\text { SCI NUTR }\end{array}$ & 124 \\
\hline 3 & $\begin{array}{l}\text { Ford- } \\
\text { lloyd et } \\
\text { al. }\end{array}$ & $\begin{array}{l}\text { Crop Wild Relatives-Undervalued, } \\
\text { Underutilized and under Threat? }\end{array}$ & 2011 & BIOSCIENCE & 124 \\
\hline 4 & $\begin{array}{l}\text { Ebert et } \\
\text { al. }\end{array}$ & $\begin{array}{l}\text { Potential of Underutilized Traditional } \\
\text { Vegetables and Legume Crops to } \\
\text { Contribute to Food and Nutritional } \\
\text { Security, Income and More Sustainable } \\
\text { Production Systems }\end{array}$ & 2014 & $\begin{array}{l}\text { SUSTAINABILITY- } \\
\text { BASEL }\end{array}$ & 124 \\
\hline 5 & $\begin{array}{l}\text { Mayes et } \\
\text { al. }\end{array}$ & $\begin{array}{l}\text { The potential for underutilized crops to } \\
\text { improve security of food production }\end{array}$ & 2012 & J EXP BOT & 108 \\
\hline 6 & Yu et al. & $\begin{array}{l}\text { Genomic prediction contributing to a } \\
\text { promising global strategy to } \\
\text { turbocharge gene banks }\end{array}$ & 2016 & NATURE PLANTS & 89 \\
\hline 7 & Jain & $\begin{array}{l}\text { Major mutation-assisted plant breeding } \\
\text { programs supported by FAO/IAEA }\end{array}$ & 2005 & $\begin{array}{l}\text { PLANT CELL } \\
\text { TISSUE ORGAN } \\
\text { CULT }\end{array}$ & 77 \\
\hline 8 & $\begin{array}{l}\text { Eshed } \\
\text { and } \\
\text { Lippman }\end{array}$ & $\begin{array}{l}\text { Revolutions in agriculture chart a course } \\
\text { for targeted breeding of old and new } \\
\text { crops }\end{array}$ & 2019 & SCIENCE & 65 \\
\hline 9 & $\begin{array}{l}\text { Vollmann } \\
\text { et al. }\end{array}$ & $\begin{array}{l}\text { Camelina as a sustainable oilseed crop: } \\
\text { contributions of plant breeding and } \\
\text { genetic engineering }\end{array}$ & 2015 & BIOTECHNOL J & 62 \\
\hline 10 & $\begin{array}{l}\text { Kamfwa } \\
\text { et al. }\end{array}$ & $\begin{array}{l}\text { Genome-Wide Association Study of } \\
\text { Agronomic Traits in Common Bean }\end{array}$ & 2015 & PLANT GENOME & 55 \\
\hline 11 & $\begin{array}{l}\text { Massawe } \\
\text { et al. }\end{array}$ & $\begin{array}{l}\text { Breeding in bambara groundnut (Vigna } \\
\text { subterranea (L.) Verdc.): strategic } \\
\text { considerations }\end{array}$ & 2005 & $\begin{array}{l}\text { AFR J } \\
\text { BIOTECHNOL }\end{array}$ & 50 \\
\hline 12 & $\begin{array}{l}\text { Dansi et } \\
\text { al. }\end{array}$ & $\begin{array}{l}\text { Diversity of the Neglected and } \\
\text { Underutilized Crop Species of } \\
\text { Importance in Benin }\end{array}$ & 2012 & SCI WORLD & 47 \\
\hline 13 & $\begin{array}{l}\text { Hammer } \\
\text { et al. }\end{array}$ & $\begin{array}{l}\text { Agrobiodiversity with emphasis on plant } \\
\text { genetic resources }\end{array}$ & 2003 & $\begin{array}{l}\text { GENET RESOUR } \\
\text { CROP EV }\end{array}$ & 43 \\
\hline 14 & DAS & Amaranthus: A promise crop of future & 2016 & Book & 42 \\
\hline
\end{tabular}




\begin{tabular}{|c|c|c|c|c|c|}
\hline No & Authors & Title & Year & Journal source & Citations \\
\hline 15 & Dansi & $\begin{array}{l}\text { Diversity, conservation and related wild } \\
\text { species of Fonio millet (Digitaria spp.) } \\
\text { in the northwest of Benin }\end{array}$ & 2010 & $\begin{array}{l}\text { GENET RESOUR } \\
\text { CROP EVOL }\end{array}$ & 40 \\
\hline 16 & $\begin{array}{l}\text { Narloch } \\
\text { et al. }\end{array}$ & $\begin{array}{l}\text { Cost-effectiveness targeting under } \\
\text { multiple conservation goals and equity } \\
\text { considerations in the Andes }\end{array}$ & 2011 & $\begin{array}{l}\text { ENVIRON } \\
\text { CONSERV }\end{array}$ & 38 \\
\hline 17 & $\begin{array}{l}\text { Shukla et } \\
\text { al. }\end{array}$ & $\begin{array}{l}\text { Efficacy of essential oils of Lippia } \\
\text { alba (Mill.) N.E. Brown and Callistemon } \\
\text { lanceolatus (Sm.) Sweet and their major } \\
\text { constituents on mortality, oviposition } \\
\text { and feeding behaviour of pulse } \\
\text { beetle, Callosobruchus chinensis L. }\end{array}$ & 2010 & J SCI FOOD AGR & 37 \\
\hline 18 & Jacobsen & $\begin{array}{l}\text { The scope for adaptation of quinoa in } \\
\text { Northern Latitudes of Europe }\end{array}$ & 2017 & $\begin{array}{l}\text { J AGRON CROP } \\
\text { SCl }\end{array}$ & 33 \\
\hline 19 & Padulosi & Bring NUS back to the table & 2014 & SUSTAINABILITY & 33 \\
\hline 20 & Masondo & $\begin{array}{l}\text { Influence of biostimulants-seed-priming } \\
\text { on Ceratotheca triloba germination and } \\
\text { seedling growth under low } \\
\text { temperatures, low osmotic potential and } \\
\text { salinity stress }\end{array}$ & 2018 & $\begin{array}{l}\text { ECOTOXICOL } \\
\text { ENVIRON SAF }\end{array}$ & 32 \\
\hline
\end{tabular}

Rastogi and Shukla's article published in the year 2013 on "Amaranth: a new millennium crop of nutraceutical values" was ranked the second most globally cited article in seed improvement of underutilized crop studies with 124 total citations. The publication considered the role of Amaranth, an underutilized crop, its high genetic diversity, phenotypic plasticity, and extreme adaptation to adverse growing conditions. The article reported amaranthus crop as a future crop with the potentials to substantiate the high food demand because it has tremendous yield potential and nutritional qualities. Ford-Lloyd's article published in the year 2011 titled "Crop Wild Relatives-Undervalued, Underutilized and under Threat?" had a similar global impact of 124 total citations (Table 2). The article focussed on seed improvement using new technological tools to enhance and conserve plant genetic resources. The study indicated the danger of losing biodiversity and the multiple threat these plant species encountered.

Ebert et al.'s article published in the year 2014 titled "Potential of Underutilized Traditional Vegetables and Legume Crops to Contribute to Food and Nutritional Security, Income and More Sustainable Production Systems" got a total citation of 121. The work revealed three underutilized legume crops (amaranth, drumstick tree, and mung beans) which possessed valuable components to attain nutritional and household income securities. The article specified the importance of seed breeding that would convert existing local landraces into competitive varieties with wide adaptation and promises commercial farming.

Among the topmost prolific authors and globally cited publications in SUC-related fields are Mayes et al's. article titled "The potential for underutilized crops to improve the security of food production" was 
published in the year 2012 which received 108 total citations. The work explained the potential of underutilized crops to improve food security in the world. It considered the genetic seed breeding potentials of the crop, ways to overcome its production and wider consumption constraints. In addition, Yu et al.'s published article in the year 2016 entitled "Genomic prediction contributing to a promising global strategy to turbocharge gene banks" had 89 total citations in the field of study (Table 2). The article explained large plant accessions in gene banks are mostly underutilized due to various resource constraints, but current genomic and analytic technologies are being optimized to mine this natural heritage. The study used sorghum accessions as a reference set, detailed analysis of the crop prediction gave new insights into a strategy that could be used to mine valuable germplasm archived in the gene banks. Other authors such as Massawe et al. 2005, Dansi et al. 2012 and Hammer et al. 2003 also researched diversified scientific field, adding values to the knowledge of seed improvement of underutilized crops (Table 2). We found few authors studying SUC-related fields from the year 2005 based on the number of nodes visually represented in figure 2 , but there was an increasing shift in the number of researchers contributing to SUC-related research from the year 2010.

\section{Author collaboration analysis and spatial distribution of SUC publications}

Based on the observed co-authorship network, a total of 485 organizations from 87 countries have participated in research and studies related to SUC (Fig. 3), the visualization of the geographic distribution of the prolific countries is based on the corresponding author's country. Published studies on SUC-related fields from the United Kingdom ranked first as the most cited countries with total citations of 402 followed by those published by researchers from India (321 citations) and China (165 citations). Articles published by researchers from Italy ranked among the most cited countries with 161 total citations followed by articles published by researchers from the USA and Benin with 132 and 107 total citations. The country with the highest number of publications in SUC studies was India (60 articles), followed by the USA (19 articles), China, Pakistan, and the UK had a production frequency of 15 (Fig. 3; Table 3). Most research linkage and networking began to get stronger from the year 2012. Also, we were able to determine countries with the strongest co-authorship linkages, where India, the United Kingdom, and Italy with 358, 329 and 380 citations respectively. Malaysia and United States have 112 and 297 citations respectively. We observed 130, 58, and 53 citations among the co-authorship network from Benin, South Africa and Ghana respectively on SUC-related researches. 
Table 3

Top ten active countries ranked by citations and number of articles in publishing seed improvement of underutilized crops

\begin{tabular}{|c|c|c|c|c|c|c|c|}
\hline Country & Freq & Country & $\mathrm{TC}$ & AAC & SCP & MCP & MCP_Ratio \\
\hline INDIA & 60 & UNITED KINGDOM & 402 & 33.50 & 10 & 2 & 0.1667 \\
\hline USA & 19 & INDIA & 321 & 10.03 & 30 & 2 & 0.0625 \\
\hline CHINA & 15 & CHINA & 165 & 20.62 & 7 & 1 & 0.125 \\
\hline PAKISTAN & 15 & ITALY & 161 & 26.83 & 6 & 0 & 0 \\
\hline UK & 15 & USA & 132 & 10.15 & 13 & 0 & 0 \\
\hline MALAYSIA & 13 & BENIN & 107 & 17.83 & 5 & 1 & 0.1667 \\
\hline NIGERIA & 12 & GERMANY & 80 & 10.00 & 8 & 0 & 0 \\
\hline BENIN & 10 & AUSTRALIA & 76 & 19.00 & 4 & 0 & 0 \\
\hline GERMANY & 9 & FRANCE & 60 & 15.00 & 3 & 1 & 0.25 \\
\hline ITALY & 9 & MALAYSIA & 46 & 7.67 & 4 & 2 & 0.3333 \\
\hline
\end{tabular}

The top three influential institutions indicated by publications and citations are; Bioversity International had the highest citations (171) in SUC related research, followed by National Botanical Research Institute, China Agricultural University, and Chinese Academic of Agricultural Science with 124 citations while Asian Vegetable Research and Development has 121 citations. (Fig. 4).

\section{Active journals, countries and themes}

The most active journal on seed improvement of underutilized crop-related studies was the journal of Genetic Resources and Crop Evolution with a g-index of 14, it started an increase in the publication on SUC from 1999 (Table 4, Fig. 5). This was followed by Acta Horticulturae journal with g-index of 5, with increase publications on SUC-related field from in the year 2001, while Agronomy journal had $4 \mathrm{~g}$-index and began active in SUC-related research since 2010. Plant Genetic Resources Characterization and Utilization journal started featuring SUC publications from the year 2009 (Table 4). Considering the interaction impact of country of studies, journal source and the most trending studies, the three-fold themes showed that researchers from India and the USA carried out the highest studies on seed genetic diversity, germplasm, and breeding of underutilized crops and published most of their findings were published in Genetic Resources and Crop Evolution Journal. Malaysia focused mostly on genetic diversity and seed breeding of underutilized crops where Bambara groundnut is well researched. China researchers carried out findings mostly on the underutilized crop conservation and genetic resources (Fig. 5). 
Table 4

Top twenty active journals in the field of seed improvement in underutilized crop

\begin{tabular}{|c|c|c|c|c|c|c|}
\hline Source & h_index & g_index & m_index & $\begin{array}{l}\text { Total } \\
\text { citations }\end{array}$ & $\begin{array}{l}\text { Publication } \\
\text { number }\end{array}$ & $\begin{array}{l}\text { Publication } \\
\text { year start }\end{array}$ \\
\hline $\begin{array}{l}\text { GENETIC RESOURCES } \\
\text { AND CROP EVOLUTION }\end{array}$ & 9 & 14 & 0.473684 & 225 & 22 & 2003 \\
\hline ACTA HORTICULTURAE & 3 & 5 & 0.214286 & 33 & 19 & 2008 \\
\hline AGRONOMY & 2 & 4 & 0.5 & 21 & 5 & 2018 \\
\hline $\begin{array}{l}\text { PLANT GENETIC } \\
\text { RESOURCES: } \\
\text { CHARACTERISATION } \\
\text { AND UTILISATION }\end{array}$ & 3 & 3 & 0.272727 & 15 & 5 & 2011 \\
\hline $\begin{array}{l}\text { AMERICAN JOURNAL OF } \\
\text { BOTANY }\end{array}$ & 2 & 3 & 0.25 & 29 & 3 & 2014 \\
\hline $\begin{array}{l}\text { BIOCATALYSIS AND } \\
\text { AGRICULTURAL } \\
\text { BIOTECHNOLOGY }\end{array}$ & 1 & 1 & 0.333333 & 4 & 3 & 2019 \\
\hline ECONOMIC BOTANY & 3 & 3 & 0.058824 & 18 & 3 & 1971 \\
\hline PLOS ONE & 2 & 3 & 0.333333 & 32 & 3 & 2016 \\
\hline VEGETOS & 1 & 1 & 0.142857 & 3 & 3 & 2015 \\
\hline $\begin{array}{l}\text { AGROFORESTRY } \\
\text { SYSTEMS }\end{array}$ & 1 & 2 & 0.2 & 5 & 2 & 2017 \\
\hline AGRONOMY-BASEL & 2 & 2 & 0.666667 & 10 & 2 & 2019 \\
\hline $\begin{array}{l}\text { AGRONOMY FOR } \\
\text { SUSTAINABLE } \\
\text { DEVELOPMENT }\end{array}$ & 1 & 2 & 0.125 & 150 & 2 & 2014 \\
\hline ERWERBS-OBSTBAU & 2 & 2 & 0.666667 & 12 & 2 & 2019 \\
\hline $\begin{array}{l}\text { HORTICULTURA } \\
\text { BRASILEIRA }\end{array}$ & 2 & 2 & 0.181818 & 28 & 2 & 2011 \\
\hline $\begin{array}{l}\text { INDIAN JOURNAL OF } \\
\text { AGRICULTURAL } \\
\text { SCIENCES }\end{array}$ & 0 & 0 & 0 & 0 & 2 & 2019 \\
\hline $\begin{array}{l}\text { JOURNAL OF } \\
\text { AGRICULTURAL } \\
\text { SCIENCE }\end{array}$ & 2 & 2 & 0.25 & 12 & 2 & 2014 \\
\hline $\begin{array}{l}\text { JOURNAL OF APPLIED } \\
\text { BOTANY }\end{array}$ & 1 & 1 & 0.045455 & 3 & 2 & 2000 \\
\hline
\end{tabular}




\begin{tabular}{|lllllll|}
\hline Source & h_index & g_index & m_index & $\begin{array}{l}\text { Total } \\
\text { citations }\end{array}$ & $\begin{array}{l}\text { Publication } \\
\text { number }\end{array}$ & $\begin{array}{l}\text { Publication } \\
\text { year start }\end{array}$ \\
\hline $\begin{array}{l}\text { JOURNAL OF THE } \\
\text { SCIENCE OF FOOD AND }\end{array}$ & 1 & 2 & 0.083333 & 38 & 2 & 2010 \\
AGRICULTURE & & & & & & \\
\hline NUCLEUS-INDIA & 1 & 2 & 0.5 & 14 & 2 & 2020 \\
PLANT AND SOIL & 2 & 2 & 0.5 & 34 & 2 & 2018 \\
\hline
\end{tabular}

\section{Analysis of the keyword}

The bibliometric analysis of the keywords provides a structured assessment of the keywords domain (Fig. 6). Five different clusters of keywords were identified represented by different colors. The total number of keywords used in the field of SUC was 1770 , only 123 were found to be mentioned at least in four occurrences in different articles.

Cluster one (red) represents the largest cluster, it had 74 keywords, 75 links with a total link strength of 107 and 12 occurrences. Its main theme was related to seed improvement of underutilized crops in the agroecosystem, with emphasis on agrobiodiversity, climate change, conservation of landraces, species diversity, genetic resources and sustainability. The current literature focuses on the cultivation of underutilized crops under traditional farming using landraces (African yam beans, millets). This cluster also features determination and morphological characterization of species diversity towards food security with more emphasis on underutilized legumes and vegetable crops such as Amaranthus, quinoa, Bambara groundnut, Vigna subterranea (Ebert, 2014).

Feldman et al. (2019) researched the high level of diversity in Bambara groundnut seeds and characterized the seeds in terms of morphology, physiology, nutrition, and DNA for the Crops for the Future program in Malaysia. Among words with high occurrences in this cluster are, 'genetic diversity, 'germplasm', 'landraces', 'domestication', 'conservation genetics' 'polymorphism', 'cultivar' 'genetic markers'. The keywords 'genetic diversity 'plant breeding' and 'germplasm are centrally positioned in the mapping, which implies that the words have strong connection with other keywords. It signifies that most research studies in SUC, focus on breeding with the use of genetic marker tools such as ISSR and conservation of the genetic traits in the landraces of underutilized crops.

Cluster two ( green) had 41 keywords, 89 links with total link strength of 129 and 11 occurrences. This indicates the seed nutritional studies of underutilized crops. It had a strong link to food security, plant breeding, food supply, nutritional values of the seeds such as plant oil, protein, and antioxidants. This cluster consists mostly of the keywords related to laboratory and controlled studies done on seed improvement of underutilized. The prominent keywords are; 'genetic variability, genetic engineering, genomics, phenotype, biotechnology, crop production, regeneration, quantitative trait locus. The role of climate change on the production of the crops and various human responses both in the past and currently on genetic variability of the crop were indicated by the keywords. The 'nutrition' keyword occurs 
eleven times with 125 total link strength, "crop" keywords occur twenty times with total link strength of 259 , while, 'breeding' occurs twenty-two times with total link strength of 177 . This indicates that these keywords are the focal and emerging themes in the published literature. Similarly, these keywords are interlinked with "genetic diversity" in cluster 1 , indicating most research works have been centered around the themes.

Cluster three (blue), consists of 37 keywords with the largest node having 109 links, total link strength of 209 and 14 occurrences focussing on seed improvement among underutilized crops. This cluster has keywords such as 'physiological stress', 'metabolism, 'seed priming', seed 'enhancement', germination,' gene expression, 'genetic analysis', 'SSR markers', 'quantitative trait locus', 'drought'. Most of the publications in the SUC-related field also focus on physiological traits of the seeds in response to stress like drought and salinity, seed enhancement strategies to improve germination, and metabolic activities in the seeds. The majority of the publication deals with the botany aspect of the plant, its nutrition, medicinal benefits, and food supply which were also the main keyword in this cluster.

Cluster four (yellow) had 23 keywords with the largest node having 113 links, total link strength of 184 and 17 occurrences focussing on evolution and domestication of underutilized crops. Analysis of the keywords in this cluster indicates that some studies have been carried out on the seed genetic polymorphism using microsatellite DNA, microsatellite repeats, phylogeny, simple sequence repeat, plant DNA, evolution, especially from the Fabaceae, family (vigna, winged bean).

Cluster 5 (purple) had 12 keywords with the largest node having 44 links, total link strength of 63 and 11 occurrences. This cluster has fewer keywords that focus on underutilized species that are mostly cultivated within the farming system such as vigna subterranean and Bambara groundnut. It contains population structure, hybridization, and gene mapping of these landraces. The scanty visibility of the purple node indicates that very weak research studies and linkage exist in the cluster especially in Africa.

The word cloud (Fig. 7) further broaden the keywords which indicated most of the crop species that have been researched are quinoa, jackfruit, African yam beans, amaranthus spp, winged beans, Dioscorea spp, indigenous vegetables. The most important keywords in SUC-related studies are "landraces", "food security", "conservation", "germplasm", "diversity", "domestication", "ethnobotany", " climate change", "yield". The upcoming keywords are "nutrition", "ex-situ conservation", "drought", "seed accession”, "biopriming", "antioxidant", "heritability", biotechnology", "genotyping” and others.

Keyword timeline view

The overlay visualization of all keywords from 1971 to 2021 clearly shows that most of the studies dealing with the landraces, breeding, food supply, regeneration, conservation genetics, medicinal herb properties of the seed conducted, became pronounced in the year 2014 (Fig. 8). Furthermore, most of these keywords belong to the second cluster of keywords, and studies related to the keyword were conducted in the early period of the evolution of the study. The studies that identify landraces, opportunities, and challenges for promoting its genetics conservation, and its awareness for nutritional 
usage began to receive attention (Galluzzi and López Noriega, 2014; Mayes et al., 2012). After the evolution of the thematic area, the focus shifted to the determination of the crop genetic variation, polymorphism in agroecosystem and yield increase, nutritional benefits, the crop response to climate change especially from the year 2015 to 2016 . Seed quality and enhancement were the focus in 2017 . The use of improved breeding tools such as microsatellite DNA, development of cultivars, gene expression done mostly in controlled environments became the central theme for studies in the year 2018. The studies conducted from 2019 till present dealt with physiological traits, metabolism, phylogeny, morphological traits on human food consumption. The emerging themes in seed improvement of underutilized crop studies are indicated by the yellow color node (Fig. 8). Cultivar development, phenotype, phylogeny, physiological characteristics of the seeds are some of the evolving themes related to SUC studies. Some other notable emerging themes are seed genetic improvement and gene bank accession. There has been gradual research progress in the SUC field since its inception where most of the earlier works focused on yield increase, awareness of its benefits to alleviate malnutrition and food insecurity. Currently, the focus is on solving most of the constraints to crop production through seed development, improved breeding tools, cultivar development, and determination of gene expression in the landraces or wild cultivars.

\section{Trending themes or topics}

This study shows the most trending topic in the SUC field to be genetic diversity followed by breeding which became most studied in the year 2016 and 2014 respectively. Among the most research underutilized crop is Bambara groundnut where considerable studies have been done since 2015. Genetic improvement, ethnobotany, yield, seed priming, molecular marker studies still have very low frequencies in the field. In addition, crop improvement and the nutritional traits in the underutilized crop especially the legume have started to receive attention from the year 2019, while the role of climate change, planting breeding of Amaranthus, and leguminous underutilized crops received research attention since the year 2011 (Figure 9).

\section{Discussion}

This study gives a visual outlook of research related to seed improvement of underutilized crops and their production. The observed gradual rise in the number of publications in the field from the last decade could be connected to an increase in awareness programmed by the United Nations 2030 agenda especially, the Sustainable Development Goal-2 to eradicate hunger, achieve food security, improve nutrition and promote sustainable agriculture by the year 2050 (Lartey, 2015). The prospects and benefits of underutilized crops to mitigate environmental risks in crop production systems, improve nutrition, generate income, maintain the health of ecosystems and contribute to the development of biological and cultural diversity were explained in the Global Plan of Action for Plant Genetic Resources for Food and Agriculture in 2011 (FAO, 2012), later expounded at the International Seminar on Crops for the XXI Century that focus on eradicating hunger and rural poverty through the use of underutilized crops. The United Nations Conference on Trade and Development (2017) reported that locally adapted breeding for drought 
or heat-tolerant crop varieties, with a focus on underutilized crops, has great potential to support climate change adaptation in agriculture. A growing number of institutions are getting active in the research and development of seed improvement of underutilized crops. Bioversity International has initiated various programmes aimed at mainstreaming certain underutilized crops in Africa, Asia and Latin America (Padulosi et al., 2013). Asia and America have been involved in various collaborative programmes and projects on improving underutilized crops (Haseen et al., 2012). FAO (2018) reports from future smart crops documentation that China, Germany, India, and Malaysia, have supported initiatives to improve conservation of germplasm, and promotion of underutilized crops to address food insecurity, poverty and climate change through on-farm conservation of local agrobiodiversity. These awareness and government initiatives could have led to a rise in the number of research publications by the authors who are exploring the prospects of underutilized crops and their re-adoption

The cluster analyses provide outputs that give the current dominant keywords in the SUC-related field and the future scope on interdisciplinary themes on SUC studies. The trending topics were closely connected to genetic diversity.

\section{Genetic diversity}

Genetic diversity is being recognized as a specific area for improvement among underutilized crops, to attain an increase in food security in nations (Muhammad et al., 2020). Genetic diversity in underutilized crops can be captured and preserved as plant genetic resources in genebank, DNA library and biorepository, which could be utilized for crop improvement to meet future food global challenges (Engels and Ebert, 2021). Bazile et al. (2016) expatiated that genetic diversity provides the opportunity for plant breeders to develop new models of varietal innovations, maintain genetic resources and improve cultivars with desirable characteristics. Dansi et al. (2012) reported that underutilized crop contributes significantly to the maintenance of genetic diversity in plant and stabilize agroecosystems.

Considerable studies are ongoing on the genetic diversity of crops such as Citrullus lanatus, where it seeds quality, viability, seed system, conservation, morphological and agronomic evaluations are being done (Achigan-Dako et al., 2009). Also, approximately $88 \%$ of the quinoa accessions are conserved in genebank in Andean region, but not exchanged globally due to highly political issues of national sovereignty (Rojas et al., 2015). Gerrano et al. (2015) evaluated the amaranthus germplasm for morphological characteristics using different statistical methods, where amaranthus genotypes were clustered into six different groups based on their genetic similarity which could help in the breeding program. Minnaar-Ontong et al. (2021) studied the genetic diversity and structure among Bambara groundnut (Vigna subterranean $\mathrm{L}$ ) landraces across south Africa using SSR markers. The population structure analyses showed most of the South African accessions were restricted to one subpopulation, which implies that Bambara landraces could form unique haplotypes in different environments. Some of the underutilized crops have gained popularity in developed countries in food trends and diets, such as quinoa, Bambara groundnut and amaranthus (Akinola et al., 2020). 
Apart from genetic diversity, other treading topics in SUC studies are; nutritional security, ecophysiology, crop modelling, food security, seed quality, breeding, and biotechnology, perceptions, climate change, postharvest, genetic resources, medicinal properties, and commercialization. Among the most dominant trending topics are germplasm conservation, genetic diversity in response to climate change, and seed systems.

\section{Genetic conservation of underutilized crop seed}

The rich diversity that exists among underutilized crops is threatened with extinction unless the germplasm is conserved and fully characterized (Kamenya et al., 2021). Most underutilized crops lack adequate genetic characterization since most germplasm collections are not maximally optimized. They are mostly conserved on-farm, rarely present in ex-situ collections and limited documentation freely available for research and development plans for targeted agro-ecologies (Engels and Ebert, 2021). Galluzzi and López Noriega (2014) gave lists of underutilized crops that have experienced breeding or evaluation programs in selected Andean countries. The collation of details such as this at different regions will help in conserving the crop genetic resources. Padulosi et al. (2013) reported the need to set up a global underutilized crop conservation program that would strengthen in situ and ex situ conservation of wild species in gene banks.

\section{Climate change and genetic diversity of underutilized crops}

Food production systems rely heavily on selected cultivars under better-endowed environments, which might be vulnerable to climate change that can affect targeted traits in crop breeding (Adelabu et al., 2020; Kamenya et al., 2021). Currently, climate change affects total precipitation, temporal dynamics and biodiversity, resulting in low variability in the genetic loci that control physical and phenotypic traits in the crop (Garcia et al., 2014). One of the adaptation strategies against climatic change is the management of genetic diversity of underutilized crops over the evolutionary period (Chiurugwi et al., 2019). These crops contain important alleles that enable them to thrive in marginal soil and extreme weather (Mabhaudhi et al. 2019). Underutilized crops have been recognized to possess tolerance traits against pests and diseases. For example, Desmodium spp intercropped with cereals suppressed Striga hermonthica by producing allelochemicals that hinder the weed root growth (Midega et al. 2017). Kamenya et al. (2021) reported that a combination of spider plant and snap beans reduce the infestations of thrips during cultivation. Foxtail millet (Setaria italica), finger millet, and quinoa (Chenopodium quinoa Willd.) exhibit high levels of tolerance to drought stress, through their osmotic adjustment, reduction of leaf area, stomal closure and genetic mechanism but increase in the crop yields are still under-researched (Hinojosa et al., 2018; Mabhaudhi et al., 2019). Despite the potentials of underutilized crops against climate change, the seed breeding strategies are still conventional and limited in innovations. Although, there is a gradual improvement in the funding initiatives for research on genome characterization and gene identification of underutilized crops (Chiurugwi et al., 2019; Padulosi, 2017; Paliwal et al., 2021). The richness of genetic diversity among underutilized crops gives incredible resilience to biotic and abiotic stresses but the identification of the genomics resources is still very limited. Exploring the potentials in the genetic 
resources of underutilized crops and the classification of valuable traits for climate change adaptation schemes requires urgent attention (Chivenge et al., 2015). Kamenya et al. (2021) reported the progress in genomes determination for more than 28 underutilized crops through gene sequencing but explained the importance of modern crop improvement tools like speed breeding, genome editing, breeding digitization and phenotyping that require high and coordinated research investment.

\section{Underutilized crop seed system and extension services}

The seeds systems of most countries have little or no regard for underutilized crops, which are mostly cultivated by the local farmers, where recycling of poor quality seeds and extremely poor yields are common (Mabhaudhi et al., 2019). Extension agents who serve as a feedback channel between farmers and the global research community to disseminate the best seed production practices have not made much progress with underutilized crops (Mabhaudhi et al., 2017). Although, some of the extension services have been digitized which helps to reach farmers using mobile-based services with verified information on the target crop in the remote villages (McCampbell et al., 2021). McMullin et al. (2021) reported cross-disciplinary teams are important for developing mainstreaming strategies for underutilized crops, but there was no clear consensus of specific measures such as production practice and pest and disease interventions, seed delivery system, past production data. However, it is necessary to structure extension services by regions, target crops, to provide improved quality cultivars and relevant management information for crops that are mostly climate-resilient and form a major part of livelihoods in specific regions (Kom et al., 2020).

Research gaps and future directions

The current study reveals the current research status and future research directions in seed genetic diversity of underutilized crops which enable the utilization of these genetic resources, similar to the seed improvement advancement in staple crops. The introduction of advanced breeding resources from staple crops to closely related climate-resilient underutilized crops is needed. In addition, optimal temperatures, humidity and growing the crops in a controlled environment just like those optimized for cereals such as wheat (Triticum aestivum L.) could be of greater benefit in crop breeding for underutilized crops (Kamenya et al., 2021; Seguí-Simarro et al., 2021). Moreover, government, private sector and international agricultural research funding should prioritize underutilized crops just as being done to most staple crops breeding schemes in many countries (Shrestha et al. 2019). Likewise, dissemination of prospects embedded in the underutilized crop will help in its conservation and usage along with the staple crops.

\section{Limitations}

The limitation in this study is that the literature was retrieved from journals indexed in Scopus and Web of Science databases only, while grey literature and publications in non-indexed journals have not been analyzed. Therefore, journals from non-English speaking countries might be underestimated and might influence the position of the top active authors, countries, institutions and journal sources. In addition, the method used to determine the frequency of each publication for each country, author, institution among multiauthor articles with the same country affiliation might not be accurate. This might have increased 
the research output of countries with greater international research collaboration. Also, the citation analysis did not take into consideration the self-citations which could create a bias in the number of citations for countries, journals, and authors.

\section{Conclusion}

This study is the first bibliometric study on seed improvement of underutilized crops. Key players, research themes, and research gaps were identified. It provides the researchers and policymakers with baseline data in seed improvement of underutilized crop studies. This study emphasizes the need for more research studies in the seed genetic diversity, conservation and utilization of underutilized crops that can help preserve the crop genetic resources, like the current seed advancement in staple crops. Also, there was inadequate international research collaboration in seed improvement of underutilized croprelated fields especially among countries in Africa regions. Finally, national and international food security organizations should encourage and fund more researchers to do more studies and collation of information on the seed improvement of underutilized crops among the regions. This study allows a better appreciation of the complex distinctions which characterize seed improvement of underutilized crops and suggests a solution to quantify these differences, through increase interventions of genetic resource conservation. Increase in collaborative researches with national and international initiatives in the genetic variability of landraces, its conservation and adaptation to climate change. These findings will improve the efficiency of underutilized crop breeding among the nations and encourage increased yield in the production areas, increase farmer income, food and nutritional security, especially in regions of water scarcity in the nations.

\section{Declarations}

\section{Conflict of interest}

The authors declare that they have no conflict of interests.

\section{Funding}

This research work was funded by the University of the Free State, Bloemfontein campus, Free State, South Africa.

\section{References}

1. Achigan-Dako E, Avohou H, Ahouanmagnagahou R, Vodouhe R, Ahanchede A (2009) Viability response of cucurbit seeds (Citrullus lanatus subsp. mucosospermus, Cucumeropsis mannii and Lagenaria siceraria) stored under various moisture content and temperature conditions. Seed Sci Technol 37:520-526 
2. Adelabu DB, Clark VR, Bredenhand E (2020) Potential for Sustainable Mountain Farming. Mt Res Dev 40:A1-A11

3. Afzal I, Rehman HU, Naveed M, Basra SMA (2016) Recent advances in seed enhancements. New Challenges in Seed Biology-Basic and Translational Research Driving Seed Technology, 47-74

4. Akinola R, Pereira LM, Mabhaudhi T, de Bruin F-M, Rusch L (2020) A review of indigenous food crops in Africa and the implications for more sustainable and healthy food systems. Sustainability $12: 3493$

5. Aliyu S, Massawe F, Mayes S (2016) Genetic diversity and population structure of Bambara groundnut (Vigna subterranea (L.) Verdc.): synopsis of the past two decades of analysis and implications for crop improvement programmes. Genet Resour Crop Evol 63:925-943

6. Anumalla M, Roychowdhury R, Geda CK, Mazid M, Rathoure AK (2015) Utilization of plant genetic resources and diversity analysis tools for sustainable crop improvement with special emphasis on rice. Int J Adv Res 3:1155-1175

7. Bailey-Serres J, Parker JE, Ainsworth EA, Oldroyd GED, Schroeder JI (2019) Genetic strategies for improving crop yields. Nature 575:109-118

8. Bazile D, Jacobsen S-E, Verniau A (2016) The global expansion of quinoa: trends and limits. Front Plant Sci 7:622

9. Chiurugwi T, Kemp S, Powell W, Hickey LT (2019) Speed breeding orphan crops. Theor Appl Genet 132:607-616

10. Chivenge P, Mabhaudhi T, Modi AT, Mafongoya P (2015) The potential role of neglected and underutilised crop species as future crops under water scarce conditions in Sub-Saharan Africa. Int $J$ Environ Res Public Health 12:5685-5711

11. Dansi A, Vodouhè R, Azokpota P, Yedomonhan H, Assogba P, Adjatin A, Loko Y, Dossou-Aminon I, Akpagana K (2012) Diversity of the neglected and underutilized crop species of importance in Benin. The scientific world journal 2012

12. Ebert AW (2014) Potential of underutilized traditional vegetables and legume crops to contribute to food and nutritional security, income and more sustainable production systems. Sustainability 6:319-335

13. Engels JM, Ebert AW (2021) A Critical Review of the Current Global Ex Situ Conservation System for Plant Agrobiodiversity. I. History of the Development of the Global System in the Context of the Political/Legal Framework and Its Major Conservation Components. Plants 10:1557

14. Feldman A, Ho WK, Massawe F, Mayes S (2019) Bambara groundnut is a climate-resilient crop: How could a drought-tolerant and nutritious legume improve community resilience in the face of climate change? "Sustainable Solutions for Food Security". Springer, pp 151-167

15. Galluzzi G, López Noriega I (2014) Conservation and use of genetic resources of underutilized crops in the Americas-a continental analysis. Sustainability 6:980-1017

16. Garcia RA, Cabeza M, Rahbek C, Araújo MB (2014) Multiple dimensions of climate change and their implications for biodiversity.Science344 
17. Gerrano AS, van Jansen WS, Adebola PO (2015) Genetic diversity of Amaranthus species in South Africa. South Afr J Plant Soil 32:39-46

18. Haseen F, Homans H, Hussein J, Marais D, McNeil G (2012) Current and Planned Research on Agriculture for Improved Nutrition. Amapping and A Gap Analysis

19. Hinojosa L, González JA, Barrios-Masias FH, Fuentes F, Murphy KM (2018) Quinoa abiotic stress responses: A review. Plants 7:106

20. Kamenya SN, Mikwa EO, Song B, Odeny DA (2021) Genetics and breeding for climate change in Orphan crops. Theor Appl Genet 134:1787-1815

21. Kom Z, Nethengwe NS, Mpandeli NS, Chikoore H (2020) Determinants of small-scale farmers' choice and adaptive strategies in response to climatic shocks in Vhembe District, South Africa. GeoJournal

22. Kumar A, Sharma V, Jain BT, Kaushik $P$ (2020) Heterosis breeding in eggplant (Solanum melongena L.): Gains and provocations. Plants 9:403

23. Lartey A (2015) End hunger, achieve food security and improved nutrition and promote sustainable agriculture. UN Chron 51:6-8

24. Mabhaudhi T, Chibarabada TP, Chimonyo VGP, Murugani VG, Pereira LM, Sobratee N, Govender L, Slotow R, Modi AT (2019) Mainstreaming underutilized indigenous and traditional crops into food systems: A South African perspective. Sustainability 11:172

25. Mabhaudhi T, Chimonyo VGP, Modi AT (2017) Status of Underutilised Crops in South Africa:Opportunities for Developing Research Capacity. J Sustain 9:1569

26. Mayes S, Massawe F, Alderson P, Roberts J, Azam-Ali S, Hermann M (2012) The potential for underutilized crops to improve security of food production. J Exp Bot 63:1075-1079

27. McCampbell M, Adewopo J, Klerkx L, Leeuwis C (2021) Are farmers ready to use phone-based digital tools for agronomic advice? Ex-ante user readiness assessment using the case of Rwandan banana farmers. The Journal of Agricultural Education and Extension,1-23

28. McMullin S, Stadlmayr B, Mausch K, Revoredo-Giha C, Burnett F, Guarino L, Brouwer ID, Jamnadass R, Graudal L, Powell W, Dawson IK (2021) Determining appropriate interventions to mainstream nutritious orphan crops into African food systems. Global Food Security 28:100465

29. Minnaar-Ontong A, Gerrano AS, Labuschagne MT (2021) Assessment of genetic diversity and structure of Bambara groundnut [Vigna subterranea (L.) verdc.] landraces in South Africa. Sci Rep $11: 1-9$

30. Mitra D, Djebaili R, Pellegrini M, Mahakur B, Sarker A, Chaudhary P, Khoshru B, Gallo MD, Kitouni M, Barik DP (2021) Arbuscular mycorrhizal symbiosis: plant growth improvement and induction of resistance under stressful conditions.Journal of Plant Nutrition,1-37

31. Muhammad I, Rafii MY, Ramlee SI, Nazli MH, Harun AR, Oladosu Y, Musa I, Arolu F, Chukwu SC, Sani Haliru B (2020) Exploration of bambara groundnut (Vigna subterranea (L.) Verdc.), an underutilized crop, to aid global food security: Varietal improvement, genetic diversity and processing. Agronomy 10:766 
32. Mukherjee D (2019) Seed Invigoration: An Effective Tool for Conservation of Endangered and Valuable Medicinal Plant. Adv Plant Physiol Vol 18 18:243

33. Mustafa M, Mayes S, Massawe F (2019) Crop diversification through a wider use of underutilised crops: A strategy to ensure food and nutrition security in the face of climate change. "Sustainable solutions for food security". Springer, pp 125-149

34. Muthamilarasan M, Singh NK, Prasad M (2019) Multi-omics approaches for strategic improvement of stress tolerance in underutilized crop species: a climate change perspective. Adv Genet 103:1-38

35. Orimoloye IR, Belle JA, Olusola AO, Busayo ET, Ololade 00 (2021) Spatial assessment of drought disasters, vulnerability, severity and water shortages: a potential drought disaster mitigation strategy. Nat Hazards 105:2735-2754

36. Padulosi S (2017) Bring NUS back to the table! GREAT Insights Mag 64:21-22

37. Padulosi S, Thompson J, Rudebjer $P$ (2013) Fighting poverty, hunger and malnutrition with neglected and underutilized species: needs, challenges and the way forward

38. Paliwal R, Adegboyega TT, Abberton M, Faloye B, Oyatomi O (2021) Potential of genomics for the improvement of underutilized legumes in sub-Saharan Africa. Legume Science

39. Popoola J, Ojuederie O, Omonhinmin C, Adegbite A (2019) Neglected and underutilized legume crops: Improvement and future prospects. In "Recent advances in grain crops research". IntechOpen

40. Rajjou L, Duval M, Gallardo K, Catusse J, Bally J, Job C, Job D (2012) Seed germination and vigor. Annu Rev Plant Biol 63:507-533

41. Rojas W, Pinto M, Alanoca C, Gomez Pando L, Leon-Lobos P, Alercia A, Diulgheroff S, Padulosi S, Bazile D (2015)"Quinoa genetic resources and ex situ conservation," FAO, Rome

42. Seguí-Simarro JM, Jacquier NMA, Widiez TH (2021) "Overview of In Vitro and In Vivo Doubled Haploid Technologies. Doubled Haploid Technology. Methods in Molecular Biology,", New York

43. Wu X, Ning F, Hu X, Wang W (2017) Genetic modification for improving seed vigor is transitioning from model plants to crop plants. Front Plant Sci 8:8

\section{Figures}




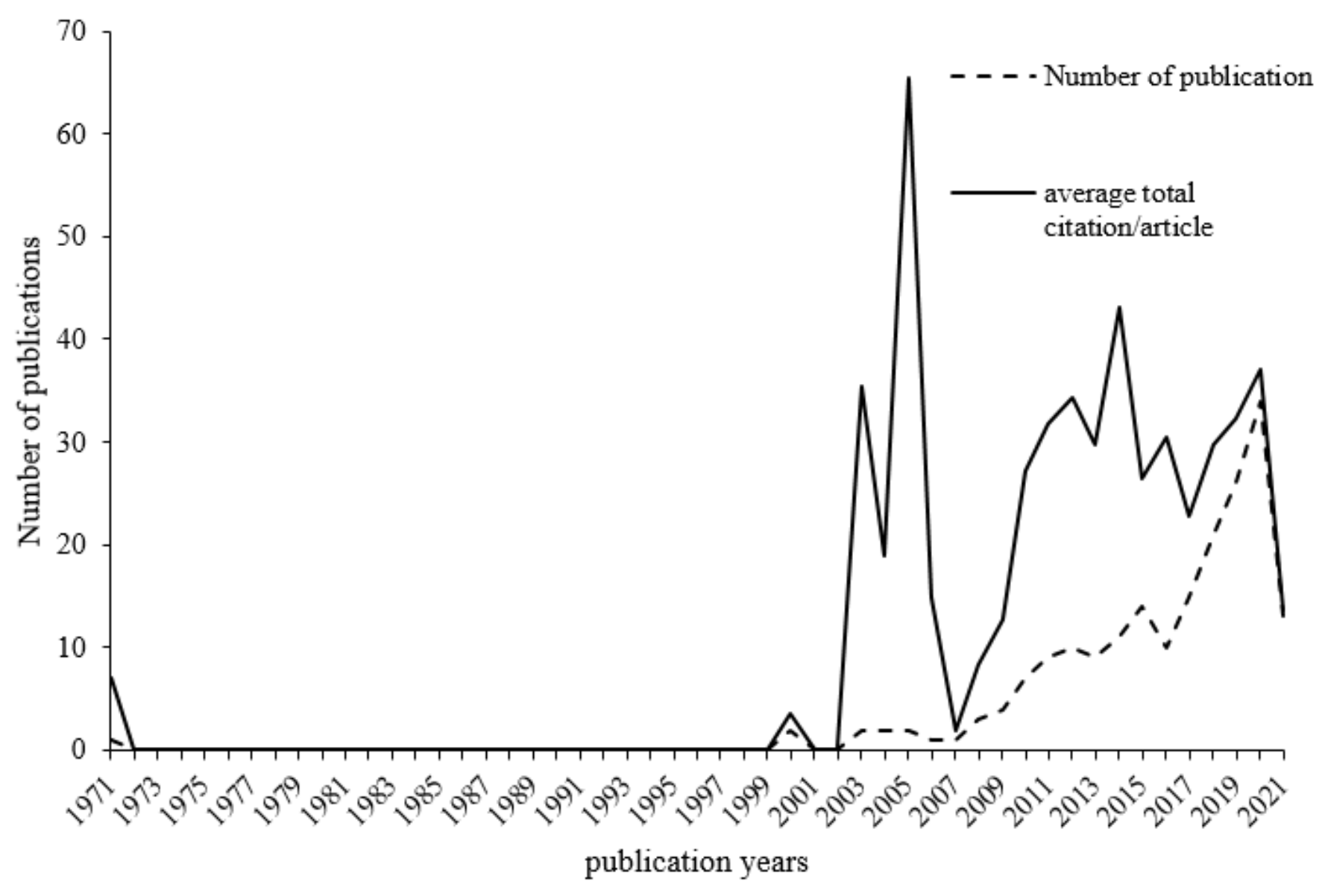

Figure 1

Number of publications and citations for SUC related studies from 1971-2021 


\section{ebert a}

masondo n;kulkarni m;finnie j;

kaldate r;rana m;sharma v;hira

dass

ho w;chai h;kendabie p;ahmad n

ruiz k;biondi s;oses r;acua-ro

massawe f;mwale s;azam-ali s;r

malik s;chaudhury r;panwar n;d

x;li x;guo t;zhu c;wu y;mit

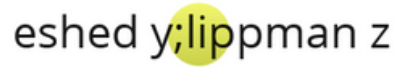

muoz-rojas m;chilton a;liyanag

dansi a;vodouhe r;azokpot

ur b;rajam m;sahijram l;k hammer k

dj y;tahi c;bi a;baudoin j;ber

vollmann j; eynck c rastogi a;shukla s

mayes s;massawe f;alderson $p ; r$

gardner e;gagn r;kendra p;m

ford-lloyd b;schmidt m;armstro

shen s; wilkes a; qian j;yin l;r shukla s;bhargava a;chatterjee bennett a;mead a;whipps j

ahmad r;malik w;anjum m

VOSviewer

gaffney j;anderson i.franks 6 ;

jacob p;avni a;bendahmane a

jains
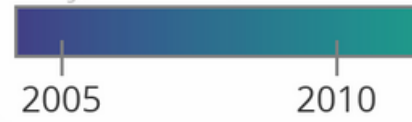

Figure 2

Most active author in SUC related studies 


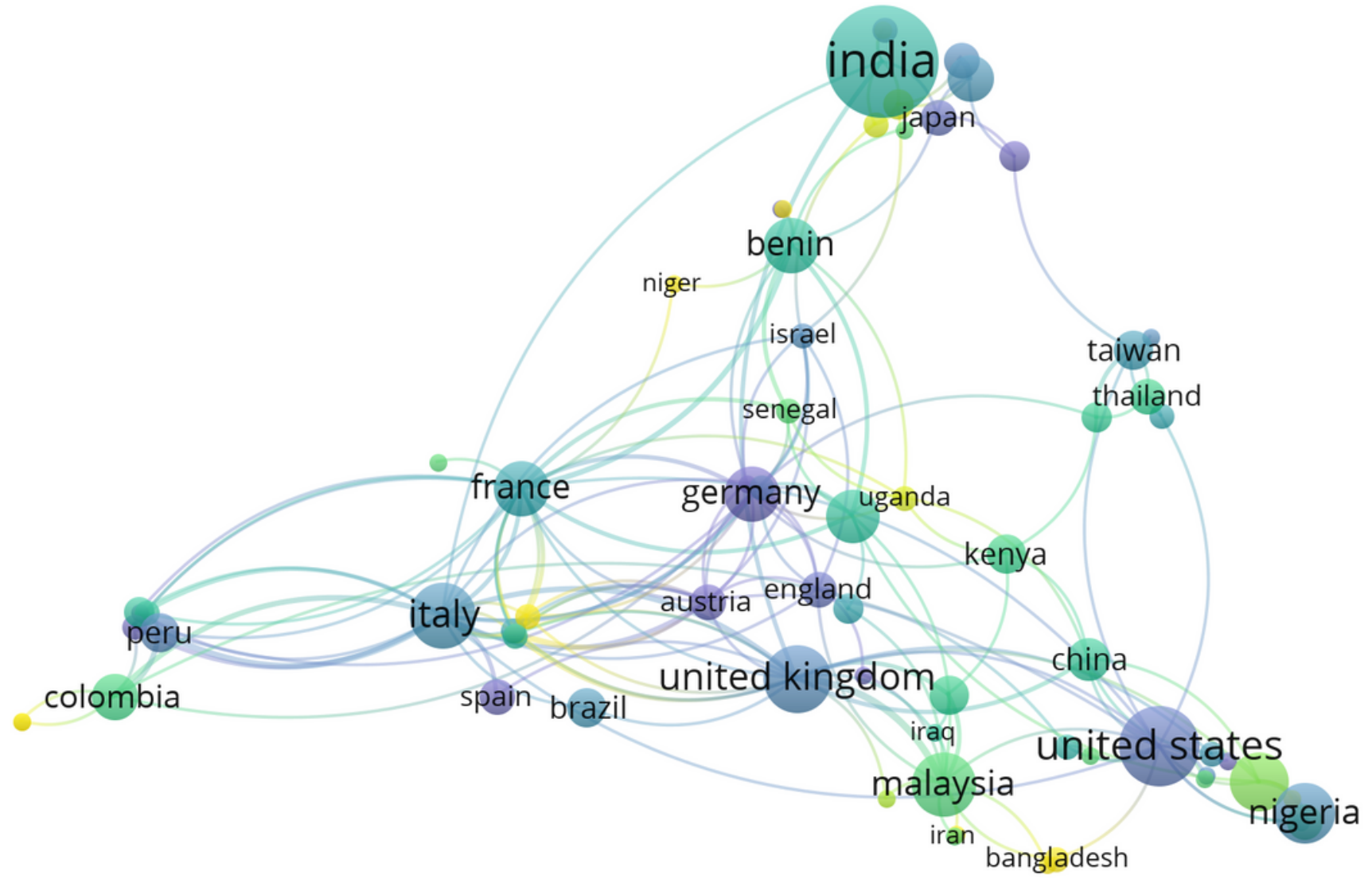

\& Vosviewer

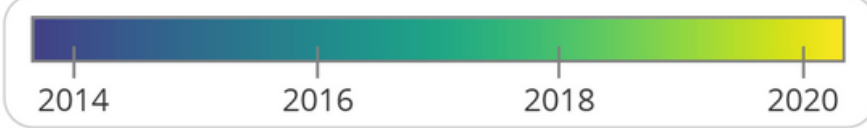

Figure 3

co authorship network among the countries 


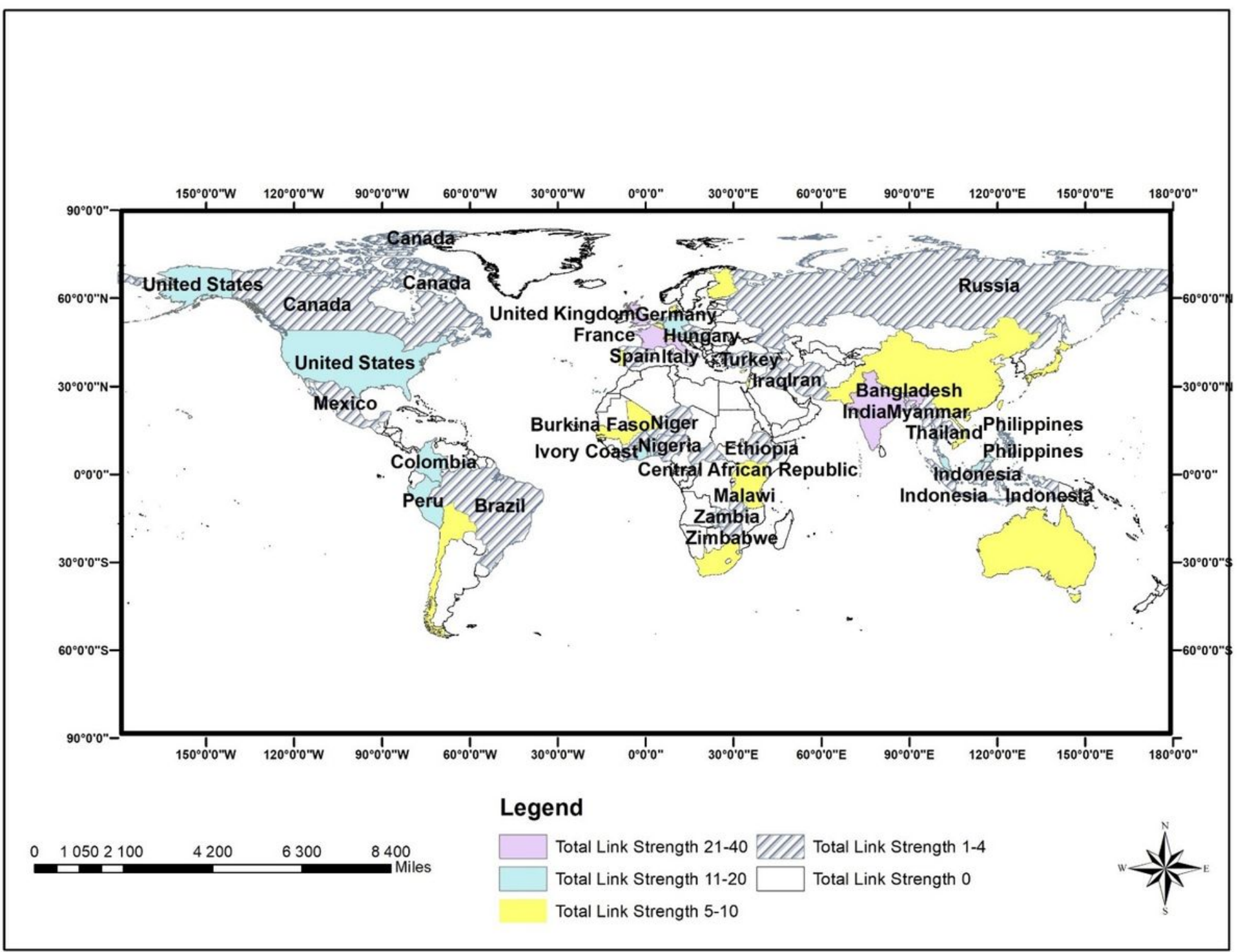

\section{Figure 4}

\section{World distribution of total link strength in the SUC research field}


world vegetable center aide au sahel et l'enfan department of plant scien

faculty of science crops for the future

\section{department of plant scien}

bioversity international

howard hughes medical ins agap department of agronomy cirad

\& VOSviewer

\section{Figure 5}

Institutional collaboration on SUC related studies 


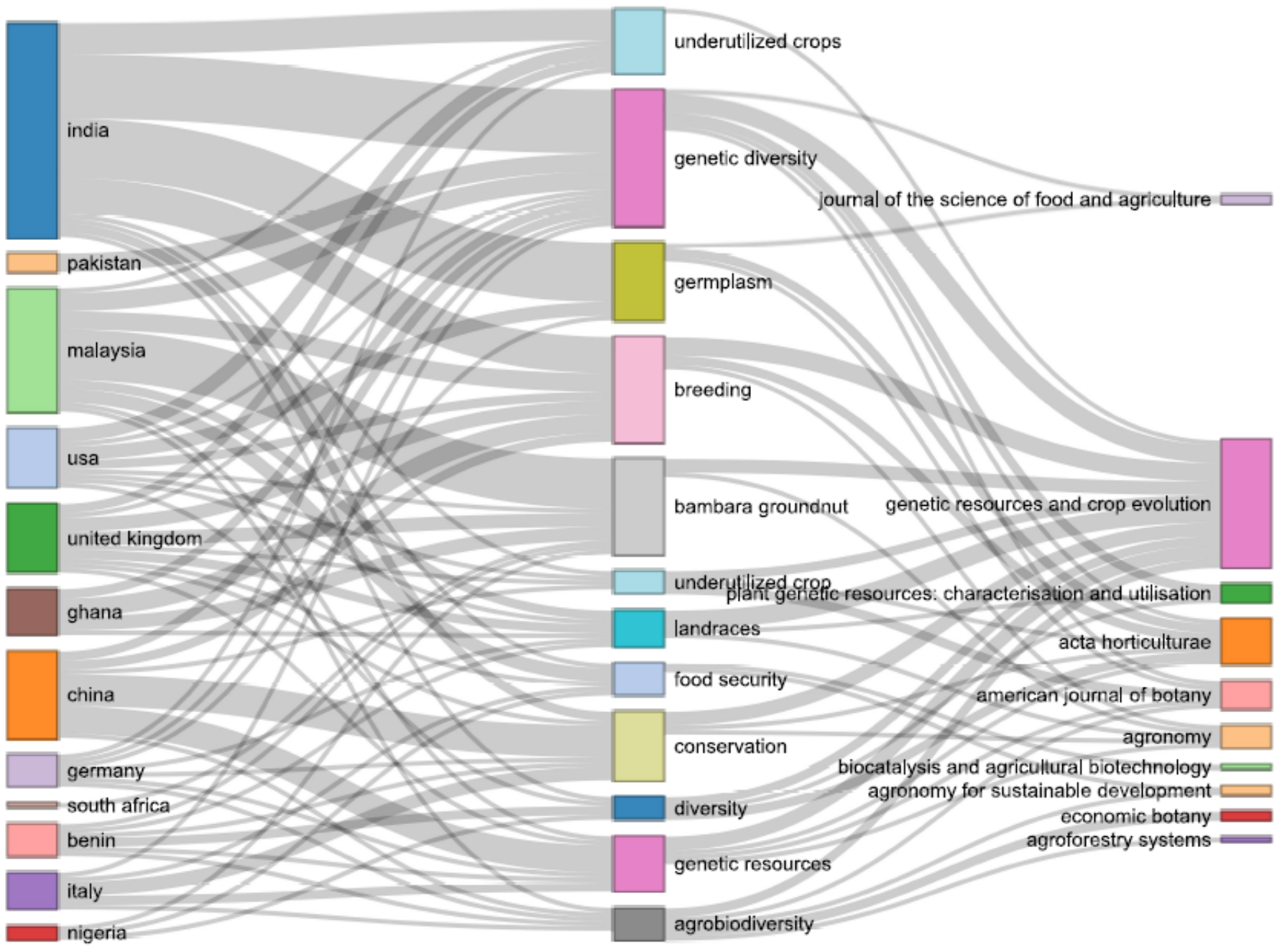

Figure 6

Three fold themes network on SUC studies 


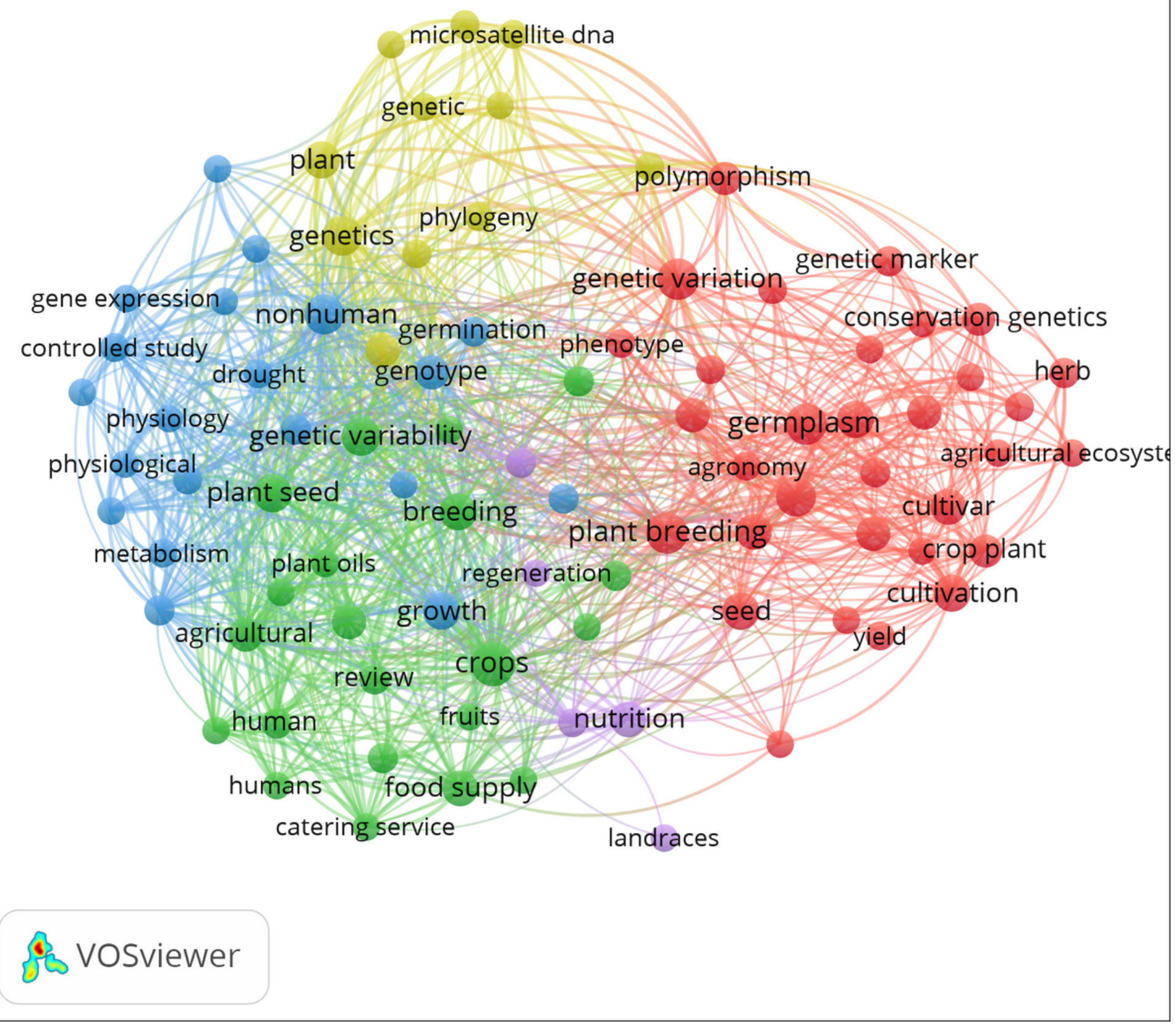

Figure 7

All keywords used in SUC related studies 
heritability african indigenous vegetables

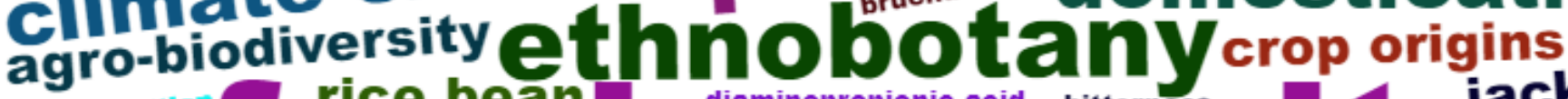

animal nutrition
andean grains

andean grains

antioxidant 2 G

egunes biofuels bolivia

yield
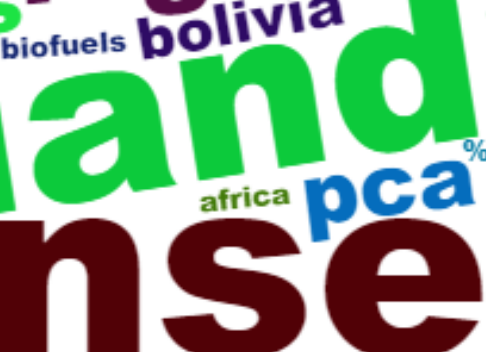

tubersafrican yam bean
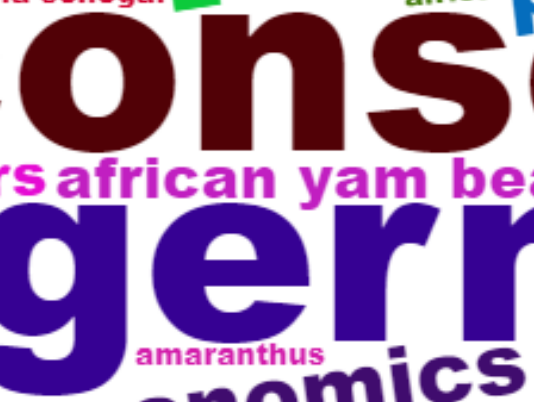

ayb fonio

biodiesel

amaranthus
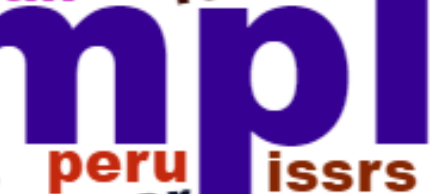

andean fruit constraints

priming genomics alue ssr

amaranthus spp

biogeography

cultivation brassicaceae

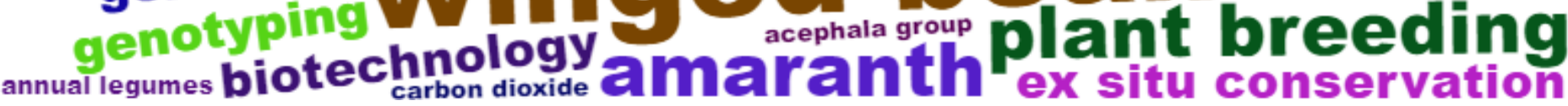

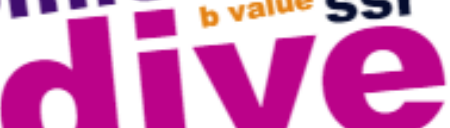

(5)
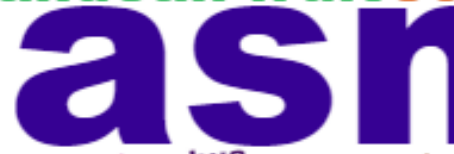

upgma

chironji

chirust

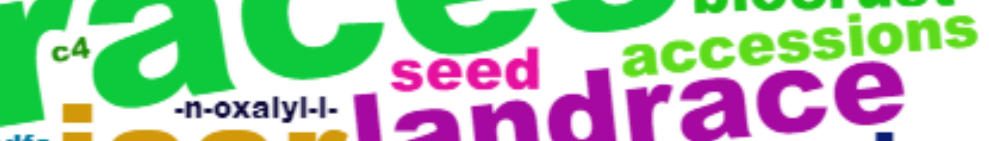

dfa
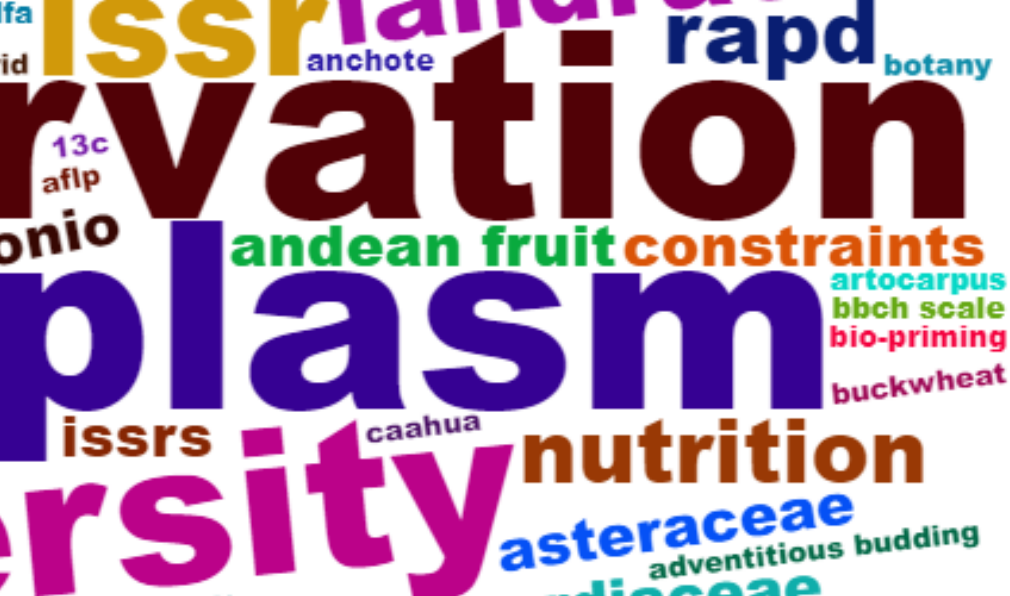

caahua

ring

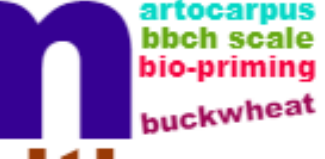

Figure 8

Wordcloud in SUC-related studies 


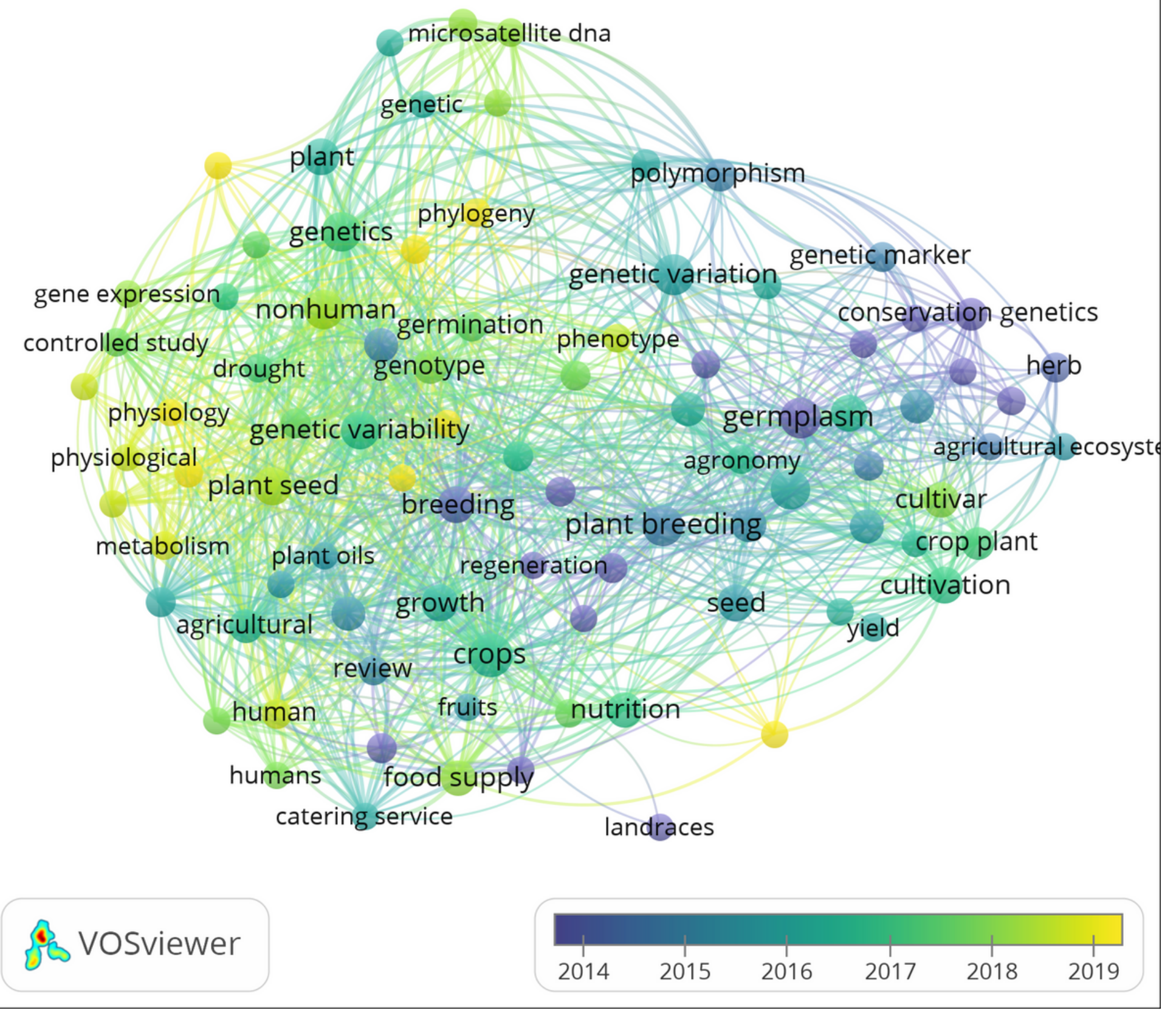

Figure 9

All keywords on SUC related studies based on timelines 


\section{Trend Topics}

genetic diversity

$3.0-$

breeding

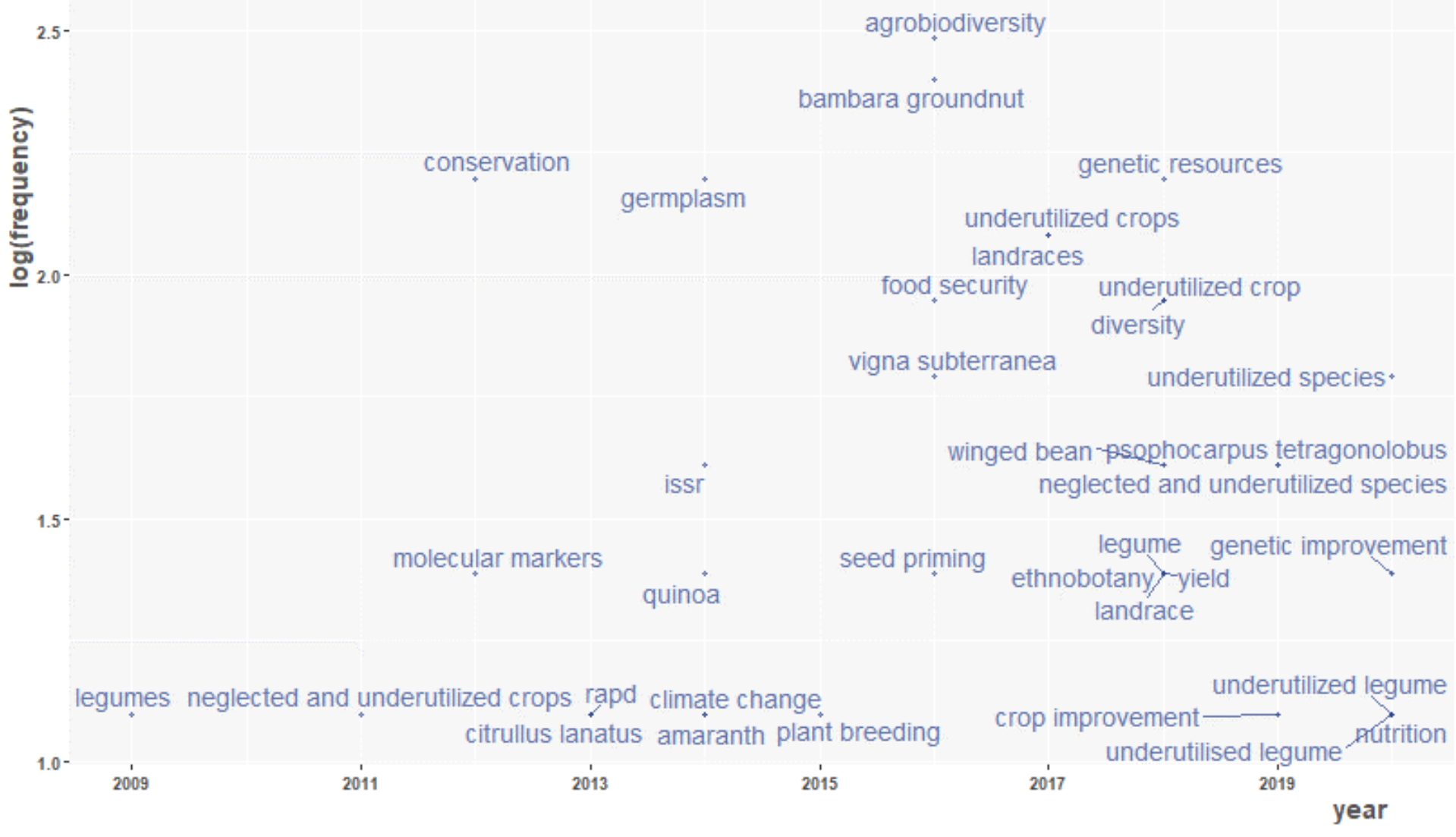

Figure 10

Trend topics in SUC related research from 2009 to 2019 